This is an author produced version of a paper published in Holzforschung.

This paper has been peer-reviewed and includes the final publisher proofcorrections and journal pagination.

Citation for the published paper:

Jie Gao, Jong Sik Kim, Nasko Terziev, Ottaviano Allegretti and Geoffrey Daniel. (2014) Chemical and ultrastructural changes incompound middle lamella (CML) regions ofsoftwoods thermally modified by the Termovuotoprocess. Holzforschung. Volume: 68, Number: 7, pp 846-859. http://dx.doi.org/10.1515/hf-2013-0221.

Access to the published version may require journal subscription. Published with permission from: De Guyter.

Standard set statement from the publisher:

http://www.degruyter.com/view/j/hfsg.2014.68.issue-7/hf-2013-0221/hf-2013-0221.xml

Epsilon Open Archive http://epsilon.slu.se 
Jie Gao, Jong Sik Kim, Nasko Terziev, Ottaviano Allegretti and Geoffrey Daniel*

\section{Chemical and ultrastructural changes in compound middle lamella (CML) regions of softwoods thermally modified by the Termovuoto process}

\begin{abstract}
Silver fir and Norway spruce wood have been thermally modified (TMW) for $3-4 \mathrm{~h}$ at $160^{\circ} \mathrm{C}, 180^{\circ} \mathrm{C}$, $200^{\circ} \mathrm{C}$, and $220^{\circ} \mathrm{C}$ by means of the thermovacuum process (Termovuoto), and the ultrastructural and chemical changes in the compound middle lamella (CML), including the middle lamella cell corner $\left(\mathrm{ML}_{\mathrm{cc}}\right)$ regions $\left(\mathrm{CML}_{\mathrm{cc}}\right)$, were investigated. Severe anatomical and histochemical changes were prominent above treatment temperatures of $200^{\circ} \mathrm{C}$; thus, woods treated at $220^{\circ} \mathrm{C}$ for $4 \mathrm{~h}$ were in focus. Immunocytochemical studies showed that noncellulosic polysaccharides, such as pectin, xyloglucan, xylan, and mannan, were significantly degraded in $\mathrm{CML}_{\mathrm{cc}}$ regions of TMWs. After treatment, the $\mathrm{CML}_{\mathrm{cc}}$ regions were composed almost entirely of modified lignin with increased amounts of acidic groups. With cytochemical staining for lignin, many electron dense particulates were detected in the $\mathrm{CML}_{\mathrm{cc}}$ regions of TMWs, indicating early degradation/ alteration by the Termovuoto treatment.
\end{abstract}

Keywords: compound middle lamella (CML), hemicelluloses, immunocytochemistry, pectin, thermal modification (TM), thermally modified wood (TMW), transmission electron microscopy (TEM)

\footnotetext{
*Corresponding author: Geoffrey Daniel, Wood Science, Department of Forest Products, Swedish University of Agricultural Sciences, P.O. Box 7008, SE-750 07 Uppsala, Sweden, e-mail: geoffrey.daniel@slu.se

Jie Gao, Jong Sik Kim and Nasko Terziev: Wood Science, Department of Forest Products, Swedish University of Agricultural Sciences, P.O. Box 7008, SE-750 07 Uppsala, Sweden

Ottaviano Allegretti: CNR- IVALSA, Timber and Trees Institute, Laboratory of Wood Drying, San Michele all'Adige, Italy
}

\section{Introduction}

The major aims of novel wood modification are the improvement of important properties of wood such as dimensional stability and resistance against biological degradation without application of toxic chemicals. The best investigated approaches are thermal treatments, acetylation, modification with maleic anhydride and 1,3-dimethylol-4,5-dihydroxy ethylene urea (DMDHEU), furfurylation, and treatment with silicone/silane and oil/ wax/paraffins (Homan and Jorissen 2004; Dieste et al. 2009; De Vetter et al. 2010; Pfriem et al. 2010; Thygesen et al. 2010; Dubey et al. 2012; Li et al. 2012). Perhaps the thermal treatments are more promising in terms of an economically viable way for production of nontoxic and durable wood products (Sandberg et al. 2013). Several commercial technologies have emerged, for example, Thermowood, Plato, oil heat treatment (OHT), Huber Holz, Bois Perdure, and rectification (Homan and Jorissen 2004; Rowell et al. 2009).

The chemistry and physical properties of thermally modified wood (TMW) are well investigated (e.g., Boonstra et al. 2007a,b; Esteves et al. 2007; Shi et al. 2007; Mburu et al. 2008). A number of microstructural studies focused on the anatomical structures, particularly damages in fibers as a result of thermal modification (TM) (Boonstra et al. 2006a,b; Awoyemi and Jones 2011; Biziks et al. 2013). The changes in the gross chemistry after TM were also extensively studied as reviewed by Esteves and Pereira (2009). Microredistribution of wood components caused by TM was observed by Fourier transform infrared (FTIR), nuclear magnetic resonance (NMR), X-ray photoelectron spectroscopy (XPS), and ultraviolet microspectrophotometry (UMSP) (Sivonen et al. 2002; Tjeerdsma and Militz 2005; Kocaefe et al. 2012; Mahnert et al. 2013). However, these methods also have limitations concerning changes at the cellular level, particularly on individual cell wall layers.

In the present work, silver fir and Norway spruce woods were treated by the Termovuoto process at temperatures between $160^{\circ} \mathrm{C}$ and $220^{\circ} \mathrm{C}$ and the wood was observed by immunocytochemical methods and transmission electron microscopy (TEM). Termovuoto is a patented technology, where the oxygen level inside the reactor is reduced by partial vacuum and heating treatment, which supports convection (Allegretti et al. 2012). In focus were the changes 
in the microdistribution of wood components, with special emphasis on the changes in the compound middle lamella (CML) regions. The expectation was that the results will lead to a better understanding of the improved microbial resistance and better dimensional stability of TMWs.

\section{Materials and methods}

Sample preparation and the TM process were described by Allegretti et al. (2012). Norway spruce (Picea abies Karst.) and silver fir (Abies alba Mill.) sapwood boards $\left(30 \times 100 \times 1000 \mathrm{~mm}\right.$, density $\left.380-440 \mathrm{~kg} \mathrm{~m}^{-3}\right)$ were treated by the Termovuoto process (thermovacuum treatment) for $3-4 \mathrm{~h}$ at $160^{\circ} \mathrm{C}, 180^{\circ} \mathrm{C}, 200^{\circ} \mathrm{C}$, and $220^{\circ} \mathrm{C}$. Matched untreated boards served as reference materials. Wood blocks $(15 \times 25 \times 50 \mathrm{~mm})$ sawn from TM boards were observed by means of light microscopy (LM) and TEM.

For LM, small blocks $(\sim 1 \times 1 \times 1 \mathrm{~cm})$ removed from matched untreated and TMW blocks were immersed in distilled water overnight. Thereafter, transverse sections $(\sim 30 \mu \mathrm{m})$ were cut with a Leitz sliding microtome (Leitz, Wetzlar, Germany) and stained with $1 \%(\mathrm{w} / \mathrm{v})$ toluidine blue in $1 \%$ borax ( $\mathrm{pH} 8.5)$. After mounting in $50 \%$ (v/v) glycerol in distilled water, sections were examined by a Leica DMLB LM (Leica, Wetzlar, Germany). Some sections were also prepared by hand sectioning or from small wood blocks immersed in distilled water over different times. Images were recorded with an Infinity X camera combined with DeltaPix InSight program (DeltaPix, Måløv, Denmark).

For TEM, small pieces $(\sim 1 \times 1 \times 3 \mathrm{~mm})$ were removed from the TMW blocks for $4 \mathrm{~h}$ at $220^{\circ} \mathrm{C}$ with a razor blade. For the control, some small pieces were also collected from matched untreated wood blocks. After fixation with a mixture of $2.5 \%(\mathrm{v} / \mathrm{v})$ glutaraldehyde and $2 \%(\mathrm{v} / \mathrm{v})$ paraformaldehyde in $0.05 \mathrm{M}$ sodium cacodylate buffer ( $\mathrm{pH}$ 7.2) for $4 \mathrm{~h}$ at room temperature (r.t.), samples were embedded in LR White resin according to Kim and Daniel (2012). To detect lignin, transverse ultrathin sections $(\sim 90 \mathrm{~nm})$ were stained with $1 \%(\mathrm{w} / \mathrm{v})$ $\mathrm{KMnO}_{4}$ in $0.1 \%$ (w/v) sodium citrate (Donaldson 1992).

For TEM immunogold labeling, ultrathin sections were incubated with monoclonal antibodies specific for $(1 \rightarrow 4)-\beta$-galactan (LM5) (Jones et al. 1997), (1 $\rightarrow 5)$ - $\alpha$-arabinan (LM6) (Willats et al. 1998), homogalacturonan (LM20) (Verhertbruggen et al. 2009), xyloglucan (LM15) (Marcus et al. 2008), xylan (LM10 and LM11) (McCartney et al. 2005), or mannan (LM21 and LM22) (Marcus et al. 2010) for 2 days at $4^{\circ} \mathrm{C}$ followed by incubation with secondary antibody conjugated with $10 \mathrm{~nm}$ colloidal gold particles (BB International, Cardiff, UK) (Kim and Daniel 2012). As a control, sections were incubated with only secondary antibody. Sections were examined by a Philips CM12 TEM (Philips, Eindhoven, Netherlands). Negative TEM films were prepared by a film scanner (Epson Perfection Pro 750, USA).

\section{Results and discussion}

The toluidine blue staining method was helpful to detect color changes in the TMWs, especially at TM above $200^{\circ} \mathrm{C}$. Anatomical changes, such as a disintegration of cell walls in the lumen side of tracheid cell walls (Figure 1c-f) and the formation of small cracks in latewood and transition wood (arrowheads in Figure 1d and f), were prominent in woods heated at and above $200^{\circ} \mathrm{C}$. To emphasize better the ultrastructural and chemical changes of the CML including the middle lamella cell corner $\left(\mathrm{ML}_{\mathrm{cc}}\right)$ regions $\left(\mathrm{CML}_{\mathrm{cc}}\right)$, the present paper will describe the TMWs treated at $220^{\circ} \mathrm{C}$ for $4 \mathrm{~h}\left(\mathrm{TMW}_{4 \mathrm{~h}, 220^{\circ} \mathrm{C}}\right)$.

\section{Histochemical observations of $\mathrm{CML}_{\mathrm{cc}}$ regions}

The color changes for Norway spruce are shown in Figure 1, while the changes for silver fir are similar (not shown). The color in thin unstained sections changed from white (Figure 1a) to orange/reddish by TM (Figure 1c and d). $\mathrm{CML}_{\mathrm{cc}}$ regions show overall stronger orange/reddish color than the secondary walls in tracheids (Figure $1 \mathrm{c}$ and d). After staining with toluidine blue, the color of $\mathrm{CML}_{\text {cc }}$ regions changed from dark blue (Figure 1b) to light orange/yellowish in $\mathrm{TMW}_{4 \mathrm{~h}, 220^{\circ} \mathrm{C}}$ (arrows in Figure 1e and f). The staining color of tracheid secondary walls also shifted overall from blue (Figure 1b) to greenish (Figure 1e and f) in $\mathrm{TMW}_{4 \mathrm{~h}, 220^{\circ} \mathrm{C}}$ with high variation in the intensity of color changes in the range of more or less intense greenish colors depending on section thickness and immersion time in water.

The staining of toluidine blue as an acidophilic blue dye works on the principle of metachromasia/orthochromasia (Sridharan and Shankar 2012). It is generally believed that the color shift from blue to yellow/or red depends on the distance between the acidic groups in tissues. The more acidic groups present in polymeric form, the stronger are the color changes, that is, the shift to yellow or red (metachromasia) from the original blue color (orthochromasia), because the acidic groups absorb the shorter wavelengths (Sridharan and Shankar 2012). Because of the shift from blue to orange/red in $\mathrm{CML}_{\mathrm{cc}}$ regions after $\mathrm{TM}$, the ratio of acidic groups in $\mathrm{CML}_{\mathrm{cc}}$ regions must have been significantly increased by the process. This may be related to new carboxylic groups generated by degradation/alteration of lignin and noncellulosic components leading mainly to the generation of acetic acid (Shafizadeh 1984; Esteves and Pereira 2009). Pectins, hemicelluloses, and lignin are significantly degraded and modified in $\mathrm{CML}_{\mathrm{cc}}$ regions of $\mathrm{TMW}_{4 \mathrm{~h}, 220^{\circ} \mathrm{C}}$ and it can be concluded that acidic groups arise during TM.

\section{Lignin cytochemistry and ultrastructure of $\mathrm{CML}_{\mathrm{cc}}$ regions}

The appearance of silver fir $\mathrm{TMW}_{4 \mathrm{~h}, 220^{\circ} \mathrm{C}}$ after staining with $\mathrm{KMnO}_{4}$ is shown in Figure 2 (Norway spruce $\mathrm{TMW}_{4} \mathrm{~h}, 220^{\circ} \mathrm{C}$ 

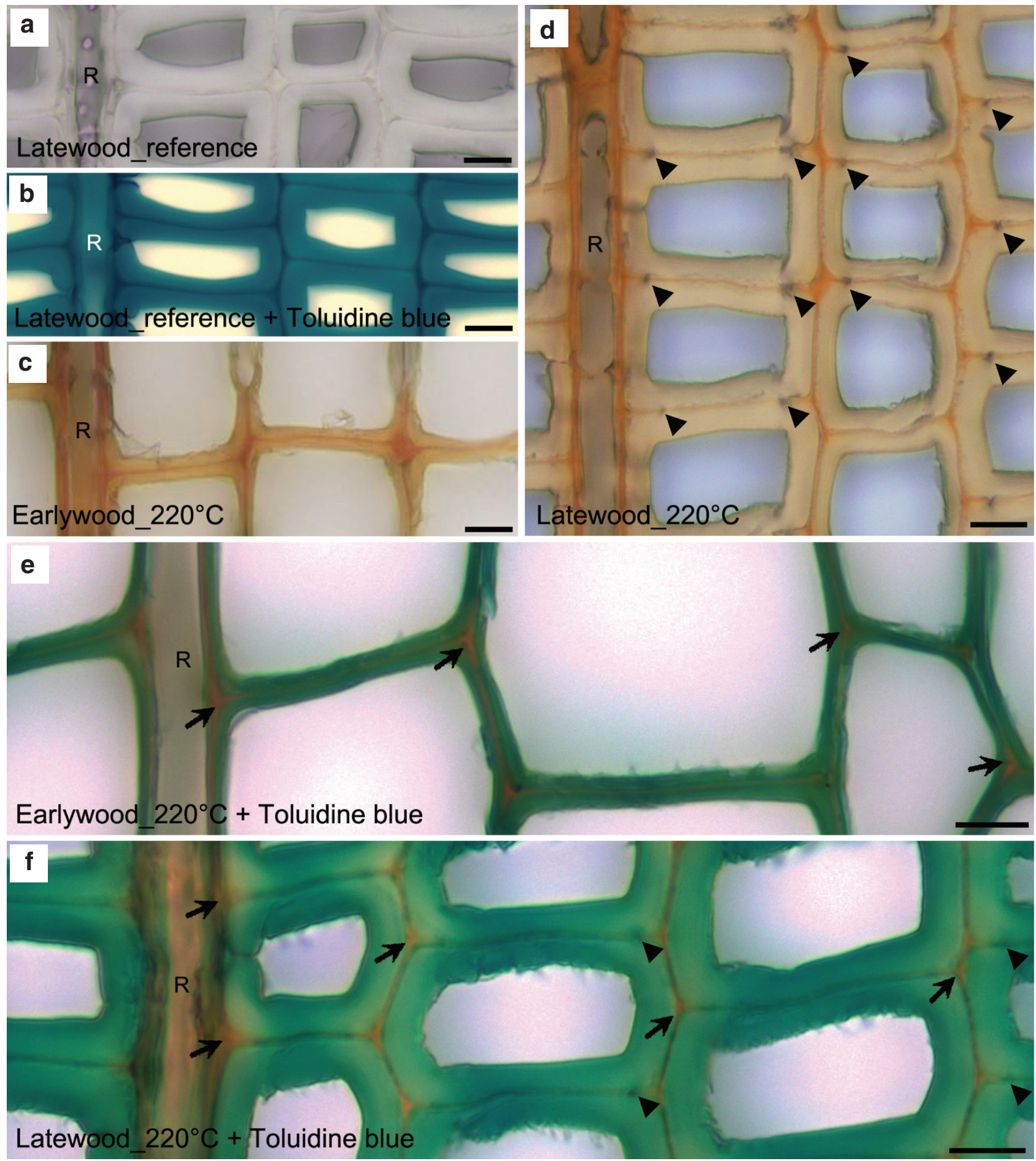

Figure 1 Histochemical observations of Norway spruce $\mathrm{TMW}_{4 \mathrm{~h}, 220 \mathrm{c}^{\circ}}$

In TMW, the native color of wood is changed from white (a) to orange/reddish color (c and d). Lignin-rich $\mathrm{CML}_{\mathrm{cc}}$ regions show stronger orange/reddish color than secondary walls ( $c$ and d) in tracheids. After staining with toluidine blue, the typical color of lignified tracheid secondary walls (blue) and $\mathrm{CML}_{c c}$ regions (dark blue) (b) changed into greenish (e and f) and orange/yellowish (arrows in e and f) in TMW, respectively. Note the disintegration or uneven surface of innermost tracheid cell walls (lumen side, $c-f$ ) and the formation of small regular cracks in latewood (arrowheads in $\mathrm{d}$ and $\mathrm{f}$ ) in TMW. Scale bar $=10 \mu \mathrm{m}$.

is similar; not shown). $\mathrm{TMW}_{4 \mathrm{~h}, 220^{\circ} \mathrm{C}}$ increased the staining intensity of $\mathrm{KMnO}_{4}$ in secondary walls and $\mathrm{CML}_{c c}$ regions of both tracheids and ray cells (Figure 2). This observation is consistent with previous chemical and physical 
Fir_reference

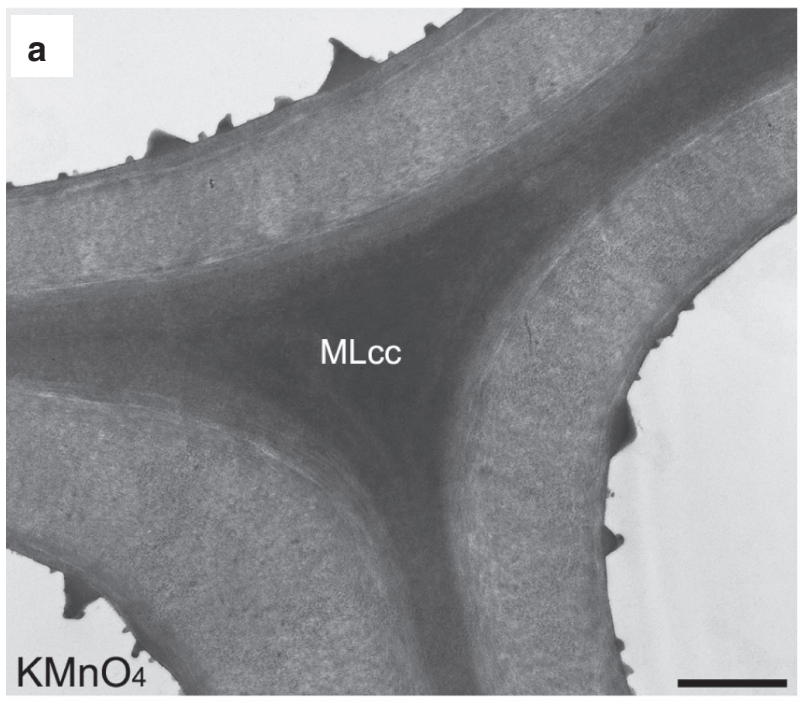

\section{b}
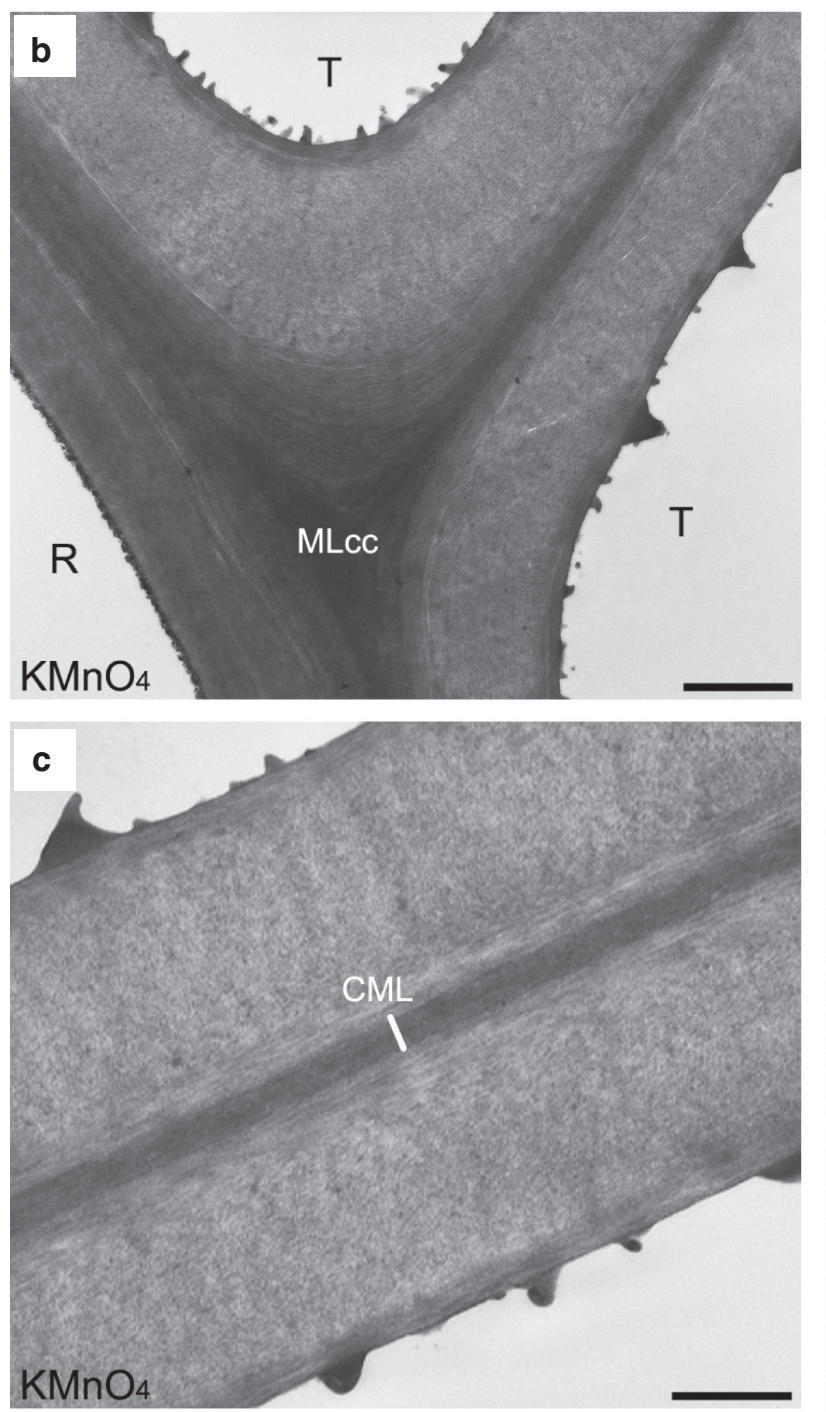

Fir_220 ${ }^{\circ} \mathrm{C}$
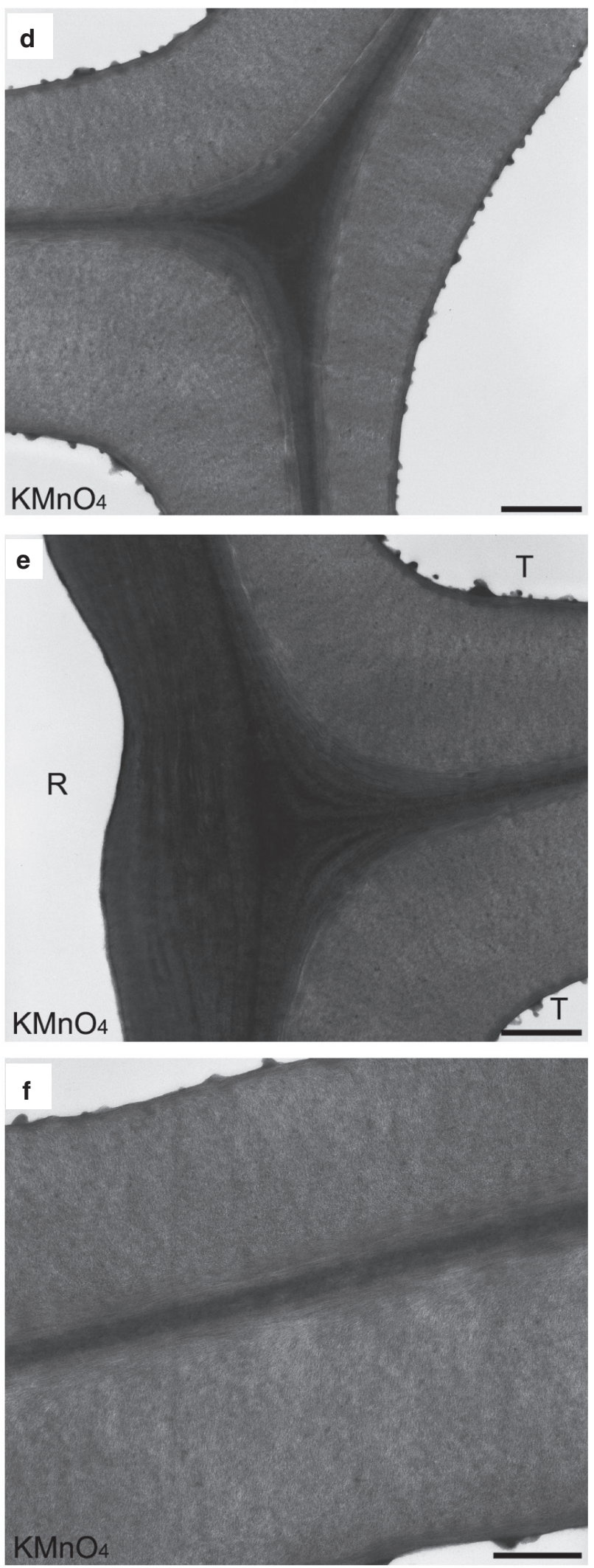

Figure 2 Changes in lignin distribution and $\mathrm{KMnO}_{4}$ staining in silver fir $\mathrm{TMW}_{4 \mathrm{~h}, 220 \circ \mathrm{C}}$.

Note the stronger staining intensity in secondary walls and $\mathrm{CML}_{c c}$ regions of TMW tracheids $(\mathrm{T})$ and ray cells $(\mathrm{R})$ ( $\left.\mathrm{d}-\mathrm{f}\right)$ compared to the untreated references $(a-c)$ and loss and reduction in size of warts in TMW (a and d). Scale bar=1 $\mu \mathrm{m}(a, b, d$, and e) and $500 \mathrm{~nm}(c$ and f). 
studies in terms of the apparent lignin content increment in TMWs (Boonstra and Tjeerdsma 2006; Windeisen and Wegener 2008; Esteves and Pereira 2009; Mahnert et al. 2013). Esteves and Pereira (2009) emphasized that the apparent high lignin content is the result of polycondensation reactions between lignin and other cell wall components. Our immunocytochemical results showed clearly that polysaccharides including pectin, xyloglucan, xylan, and mannan in the $\mathrm{CML}_{\mathrm{cc}}$ regions are significantly degraded during TM. By this degradation and lignin modification, the accessibility of $\mathrm{KMnO}_{4}$ for staining lignin is also elevated.

At high magnifications, TEM observations show many electron dense particulates in $\mathrm{CML}_{c c}$ regions (arrows in Figure 3a) of tracheids and ray cells. Although less prominent than $\mathrm{CML}_{c c}$ regions, similar particulates are also visible in the CML (arrows in Figure 3b). In previous studies of pyrolysed Scots pine (Zollfrank and Fromm 2009; Brandt et al. 2010), notable changes of $\mathrm{CML}_{\mathrm{cc}}$ structure were detected at temperatures between $200^{\circ} \mathrm{C}$ and $250^{\circ} \mathrm{C}$. Obviously, the electron dense particulates in the $\mathrm{CML}_{\mathrm{cc}}$ regions observed here are due to early degradation of the supramolecular structures. In the quoted studies, the typical CML structure of tracheids in pyrolysed Scots pine was completely lost after TM at $300^{\circ} \mathrm{C}$ for $2 \mathrm{~h}$. The strong contrast with $\mathrm{KMnO}_{4}$ is a clear hint to lignin degradation/alteration in these regions. Loss and reduction in size of warts that contain high lignin and xylan (Kim et al. 2011) was also frequently observed in silver fir $\mathrm{TMW}_{4 \mathrm{~h}, 220^{\circ} \mathrm{C}}$ tracheids (Figure 2a and d).

\section{Detection of pectic polysaccharides in $\mathrm{CML}_{\mathrm{cc}}$ regions}

The distribution of noncellulosic polysaccharides in $\mathrm{CML}_{\mathrm{cc}}$ regions has been examined in the earlywood by immunogold labeling. Immunocytochemical methods based on glycan-directed probes allow high resolution with hints to the microdistribution of cell wall components (Knox 2008). In particular, TEM immunogold labeling is very promising with this regard.

Both silver fir and Norway spruce show similar distribution patterns of pectic polysaccharides in $\mathrm{CML}_{\mathrm{cc}}$ regions in the reference and $\mathrm{TMW}_{4 \mathrm{~h}, 220^{\circ} \mathrm{C}}$. LM5 (galactan) and LM6 (arabinan), frequently used to determine the presence of rhamnogalacturonan-I (RG-I) in plant cell walls (Knox 2008), were abundant in $\mathrm{CML}_{\mathrm{cc}}$ regions of reference tracheids and ray cells of silver fir (Figure $4 a-c$ and $j$ ). This was also the case in Norway spruce (not shown) but was almost absent in $\mathrm{TMW}_{4 \mathrm{~h}, 220^{\circ} \mathrm{C}}$ (Figure $4 \mathrm{~d}-\mathrm{i}, \mathrm{k}$, and l). LM5
(Figure 4b) and LM6 (not shown) epitopes detected in the outermost and innermost ray cell walls of reference specimens, respectively, were absent in TMW (Figure 4e, h). LM20 epitopes (detects high methyl esterified homogalacturonan, $\mathrm{HG}$ ) were abundant in $\mathrm{CML}_{\mathrm{cc}}$ regions of untreated tracheids and ray cells (Figure $5 \mathrm{a}-\mathrm{c}$ ) and bordered pit membranes of untreated tracheids (Figure 5d). However, in $\mathrm{TMW}_{4 \mathrm{~h}, 220^{\circ} \mathrm{C}}$, LM20 epitopes were absent in both $\mathrm{CML}_{\mathrm{cc}}$ regions and bordered pit membranes of silver fir (Figure 5e-h) and Norway spruce (Figure 5i-l).

Silver fir and Norway spruce have fairly similar distribution patterns of xyloglucan and xylan epitopes (hemicellulosic polysaccharides) in both reference and $\mathrm{TMW}_{4 \mathrm{~h}, 220^{\circ} \mathrm{C}}$. LM15 (xyloglucan) epitopes are abundant in $\mathrm{CML}_{\mathrm{cc}}$ regions of untreated tracheids and ray cells (Figure $6 \mathrm{a}-\mathrm{c}$ ) but only sparsely detectable in $\mathrm{TMW}_{4 \mathrm{~h}, 220^{\circ} \mathrm{C}}$ (Figure 6d-i). LM11 (high substituted xylan) epitopes are also abundant in $\mathrm{CML}_{\text {cc }}$ regions of untreated silver fir (Figure 7a) and Norway spruce (Figure $7 \mathrm{~b}$ ) tracheids but more sparsely present in $\mathrm{TMW}_{4 \mathrm{~h}, 220^{\circ} \mathrm{C}}($ Figure $7 \mathrm{~d}$ and e). Although less prominent than LM11 labeling, a decrease of LM10 (low substituted xylan; not shown) epitopes was also visible in $\mathrm{CML}_{\mathrm{cc}}$ regions of $\mathrm{TMW}_{4 \mathrm{~h}, 220^{\circ} \mathrm{C}^{\circ}}$ Overall, changes of LM10 and LM11 epitopes in CML regions were somewhat unclear. With localization of mannan polymers, LM21 (not shown) and LM22 (Figure 7c) epitopes were present in $\mathrm{ML}_{\mathrm{cc}}$ regions of untreated silver fir tracheids but only sparsely detected in untreated Norway

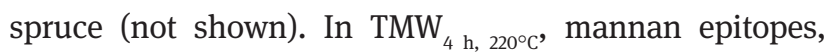
particularly LM22 (Figure 7f), show significant reduction in $\mathrm{ML}_{\mathrm{cc}}$ regions of silver fir tracheids with some variation between tracheids. Like xylan epitopes, changes of mannan epitopes in CML regions were unclear than in the case of pectins.

Distributional changes of noncellulosic polysaccharides in $\mathrm{CML}_{\mathrm{cc}}$ regions of $\mathrm{TMW}_{4 \mathrm{~h}, 220^{\circ} \mathrm{C}}$ can be clearly detected by immunogold labeling. After TM, epitopes of pectin and xyloglucan were almost absent in $\mathrm{CML}_{\mathrm{cc}}$ regions and the presence of xylan and mannan was also significantly reduced. However, several limitations should be considered in terms of the interpretation of the epitope distribution. To these belong the possible masking effects in labeling between chemical components and limitation of monoclonal antibodies to detect the whole polysaccharide structure. Nevertheless, our results are consistent with degradation of noncellulosic polysaccharides in $\mathrm{CML}_{\mathrm{cc}}$ regions, as it is proven that degradation of polysaccharides commences at relatively low temperatures (Kollman and Fengel 1965; Esteves and Pereira 2009). In $\mathrm{TMW}_{4 \mathrm{~h}, 220^{\circ} \mathrm{C}}$ in this study, $\mathrm{CML}_{\mathrm{cc}}$ regions of silver fir and Norway spruce wood cells appear to be composed almost entirely of lignin as a result of the 

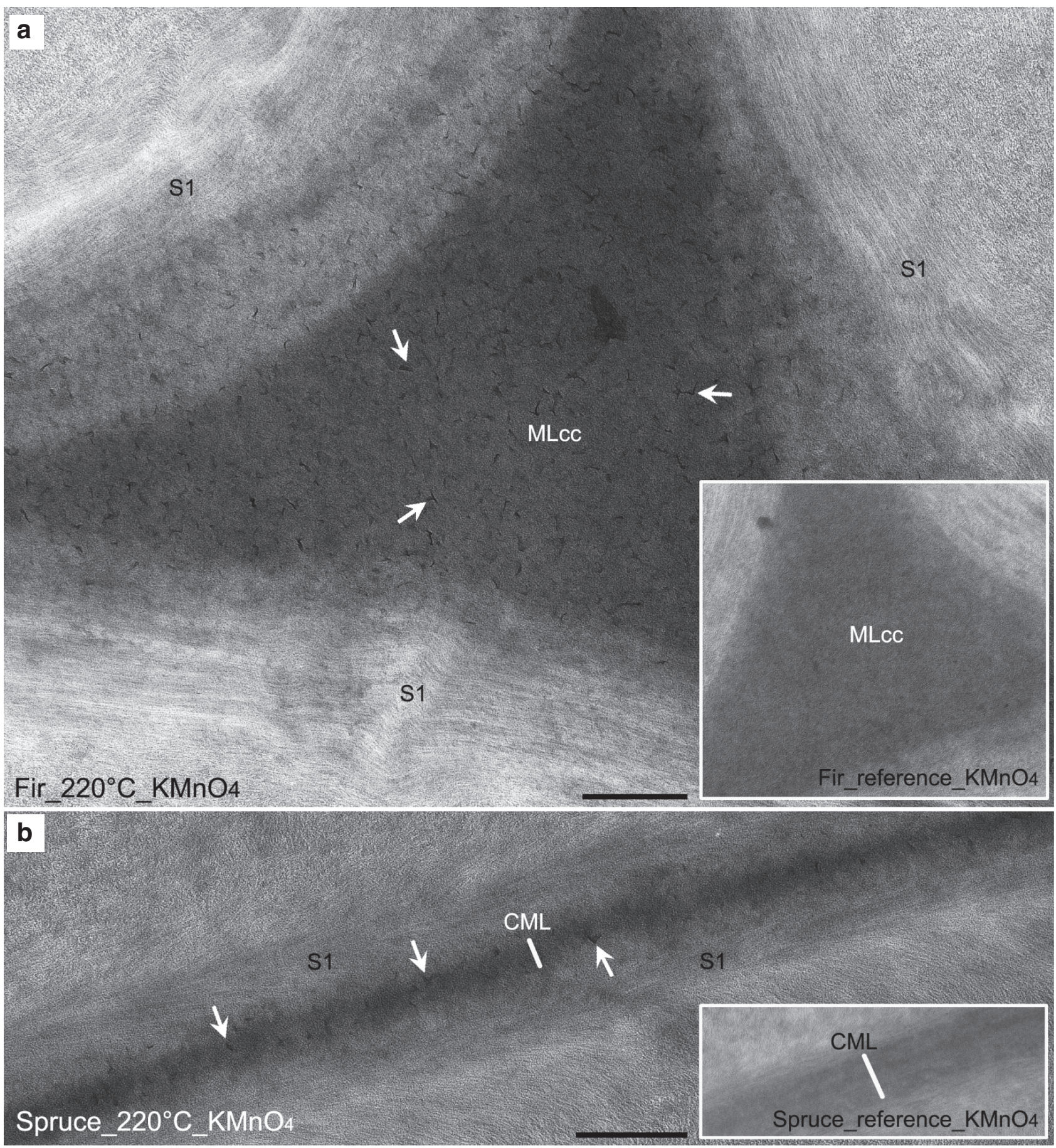

Figure 3 Changes in ultrastructure of $\mathrm{KMnO}_{4}$ stained $\mathrm{CML}_{c c}$ regions of silver fir (a) and Norway spruce (b) $\mathrm{TMW}_{4 \mathrm{~h}, 220^{\circ} \mathrm{C}}$ tracheids. Note the formation of electron dense particulates (arrows in a and b) in $\mathrm{CML}_{c c}$ regions of $\mathrm{TMW}$ tracheids. Insets show $\mathrm{CML}_{c c}$ regions of untreated silver fir (a) and Norway spruce (b) tracheids. Scale bar $=500 \mathrm{~nm}$.

increment of the relative lignin concentration caused by polysaccharide degradation and condensation with lignin.

Considering chemical changes in TMWs, previous studies have primarily focused on changes in cellulose, hemicelluloses, and lignin in secondary walls (Esteves and Pereira 2009). Nonstructural components such as pectins and xyloglucan have not been considered, presumably because these polysaccharides are minor components and exist mainly in $\mathrm{CML}_{\mathrm{cc}}$ regions. However, 


\section{Fir_reference}
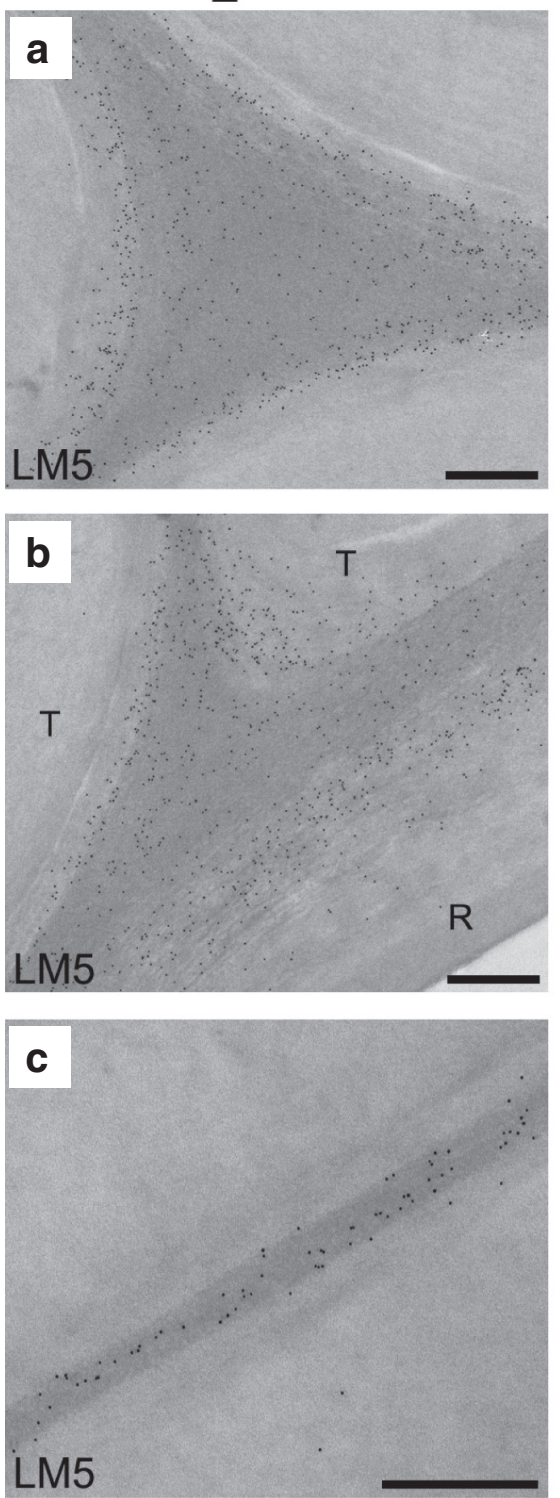

\section{j}

LM6
Fir_220 $20^{\circ} \mathrm{C}$
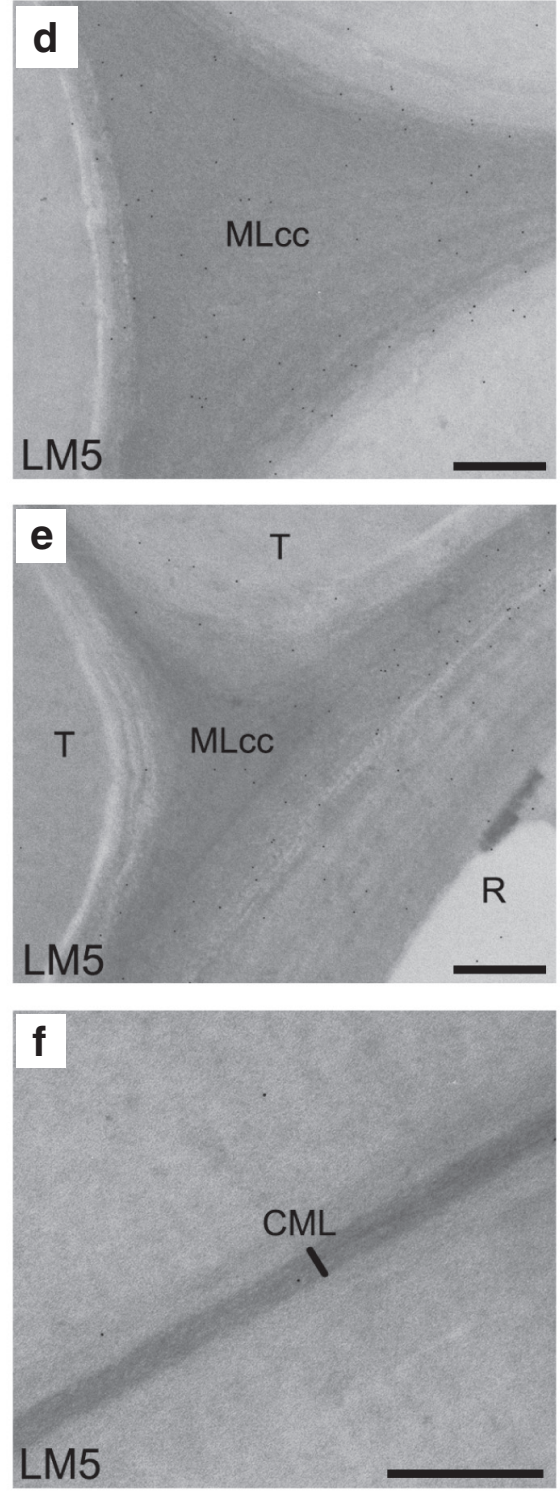

\section{k}

MLcC

MLCC

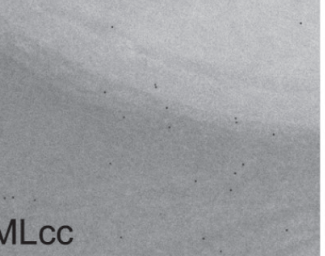

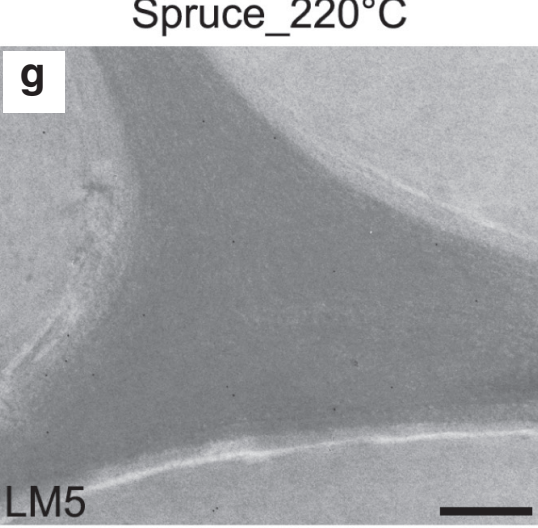
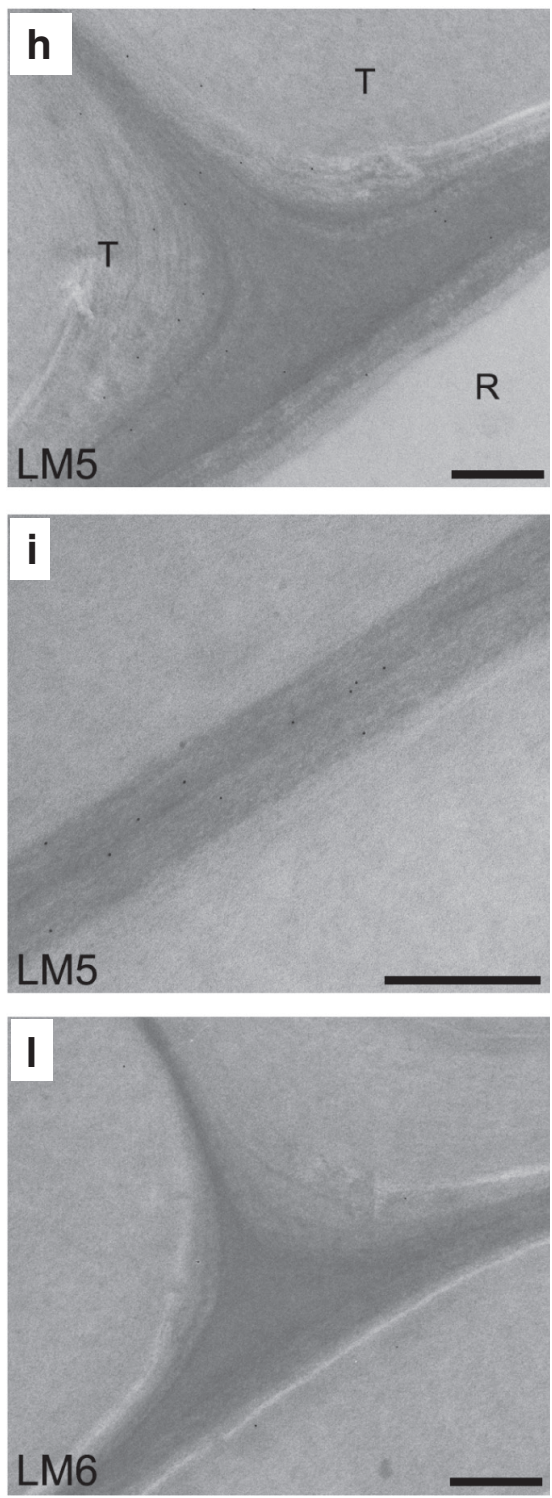

Figure 4 Detection of (1 $\rightarrow 4)$ - $\beta$-galactan (LM5 and galactan) and (1 $\rightarrow 5)$ - $\alpha$-arabinan (LM6 and arabinan) in silver fir and Norway spruce $\mathrm{TMW}_{4 \mathrm{~h}, 220^{\circ} \mathrm{C}}$.

Note the significant reduction of galactan epitopes in $\mathrm{CML}_{c c}$ regions and outer ray cell walls of silver fir (d-f) and Norway spruce (g-i) TMW tracheids $(T)$ and ray cells $(R)$ compared with untreated parts $(a-c)$. Arabinan epitopes in $C_{M L}$ regions of silver fir $(k)$ and Norway spruce $(l)$ TMW tracheids were also absent despite of their abundant presence in untreated references (j). Scale bar=500 $\mathrm{nm}$. 
Fir_reference
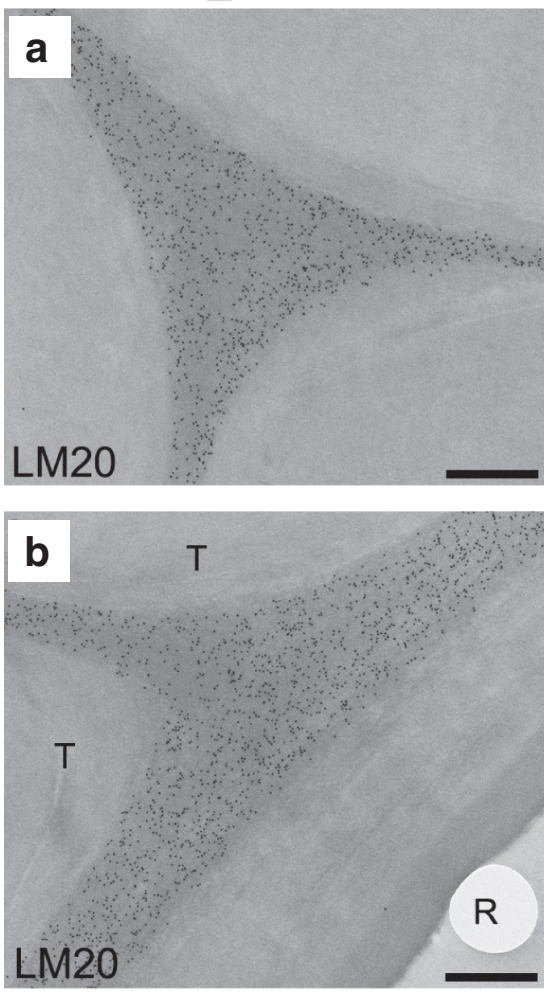

\section{c}
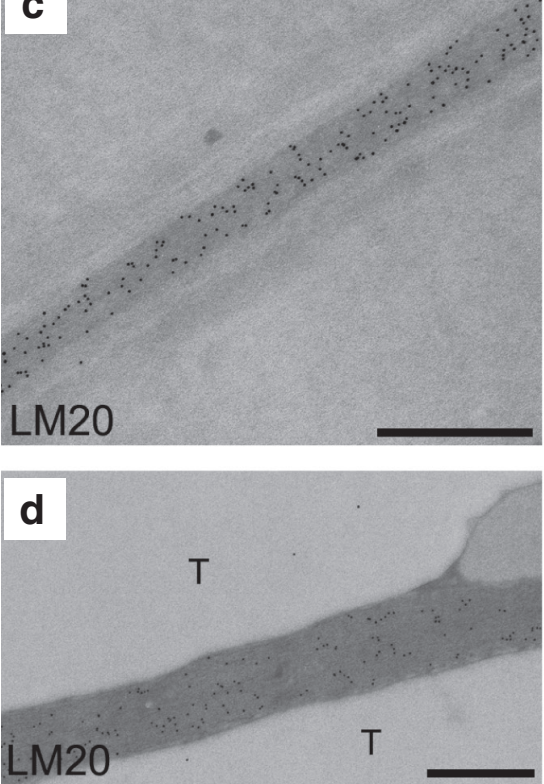

Fir_220 $20^{\circ}$
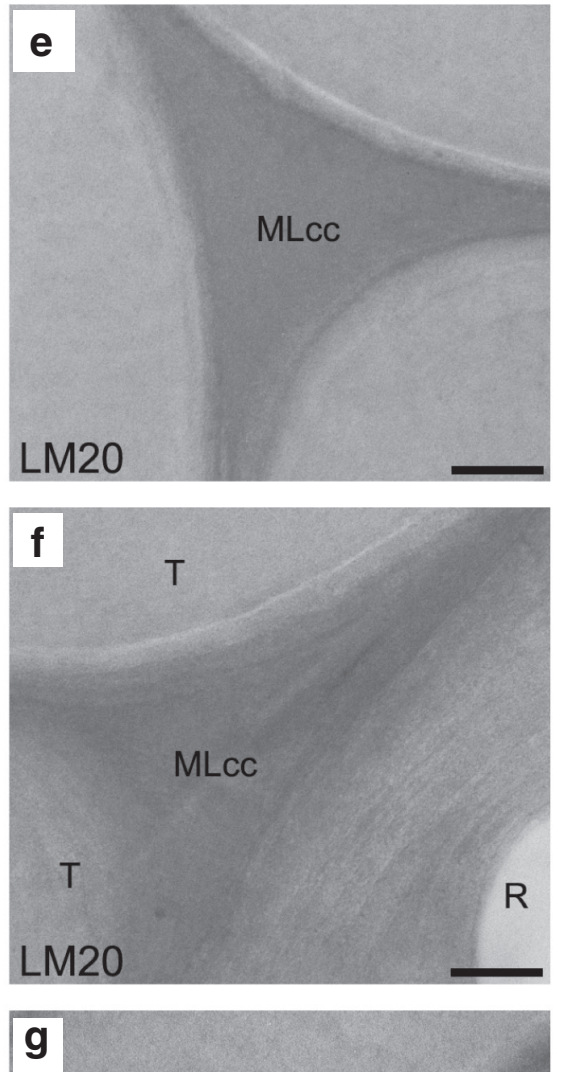

LM20

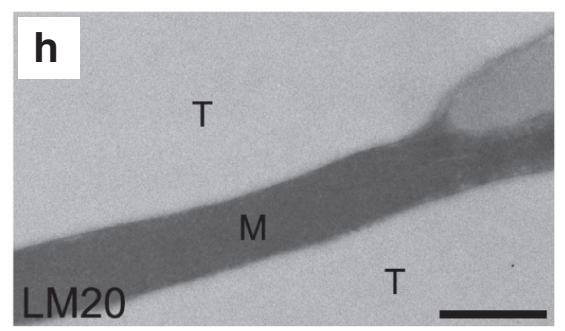

Spruce_ $220^{\circ} \mathrm{C}$

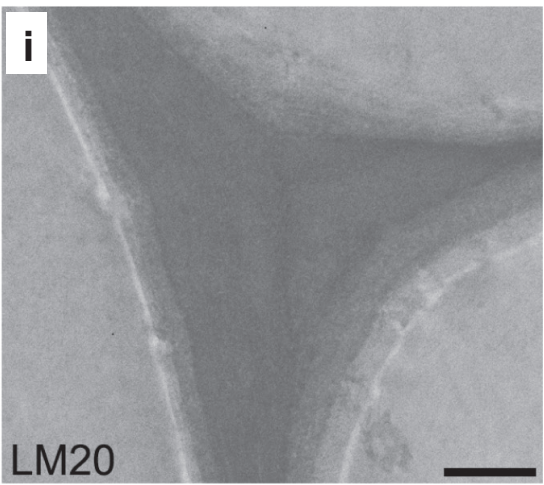

j $\quad T$

T

R

T

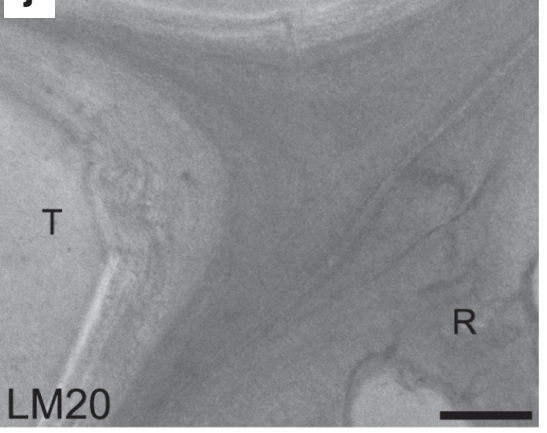

$\mathbf{k}$

\section{LM20}

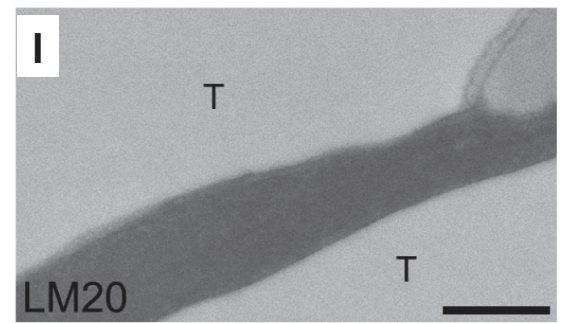

Figure 5 Detection of homogalacturonan ( $\mathrm{HG}$ and LM20) in silver fir and Norway spruce $\mathrm{TMW}_{4 \mathrm{~h}, 220^{\circ} \mathrm{C}}$. HG epitopes are absent in $C M L_{c c}$ regions and bordered pit membranes $(M)$ of silver fir $(e-h)$ and Norway spruce (i-l) TMW tracheids $(T)$ and ray cells $(R)$, but they are abundant in untreated references $(a-d)$. Scale bar $=500 \mathrm{~nm}$.

pectins and xyloglucan are known to play an important role in adhesion between plant cells. This explains the known deterioration of physical properties of TMWs. Degradation of pectin and xyloglucan in TMWs is also related to the formation of microcracks in $\mathrm{CML}_{\mathrm{cc}}$ regions and easy separation of wood cells. During fungal decay, pectin is thought to be an important polymer for early stages of fungal colonization. It was demonstrated that hydrolysis 
Fir_reference
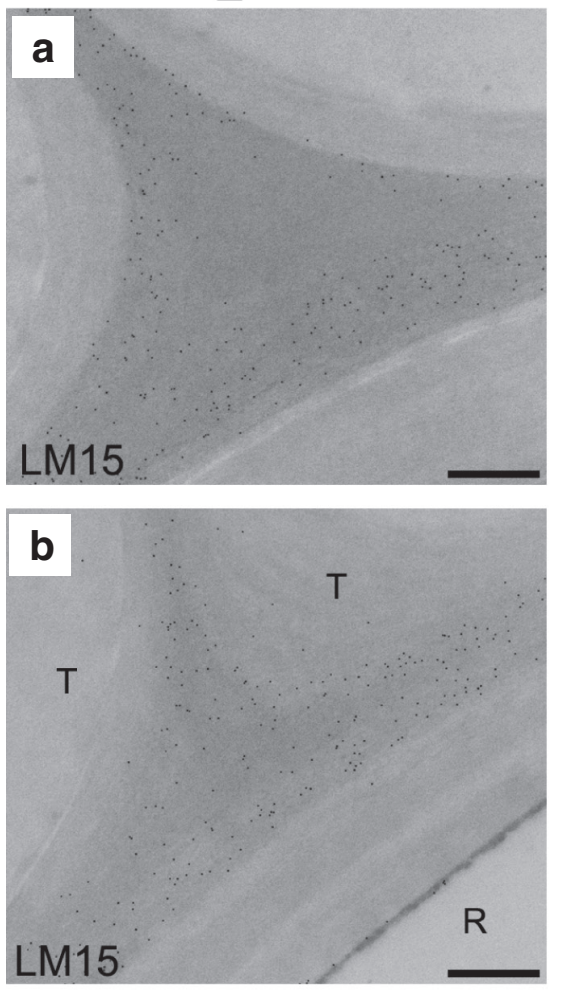

\section{c}

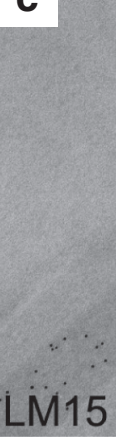

Fir_220 $20^{\circ}$
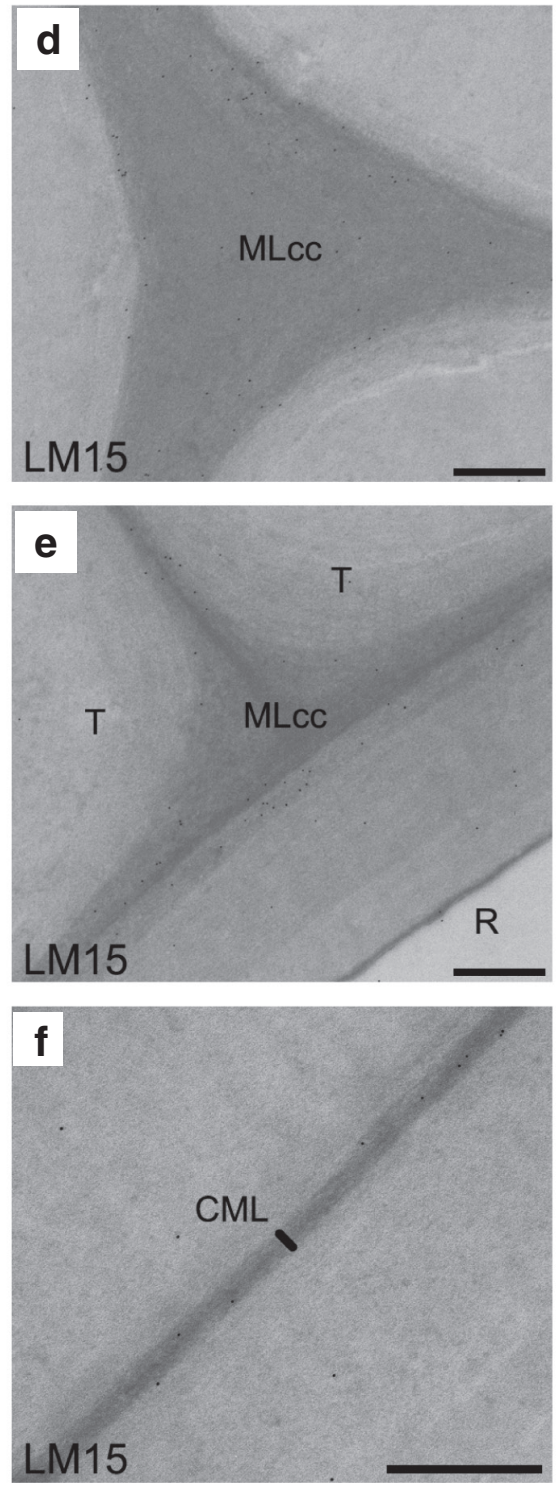

Spruce_ $220^{\circ} \mathrm{C}$
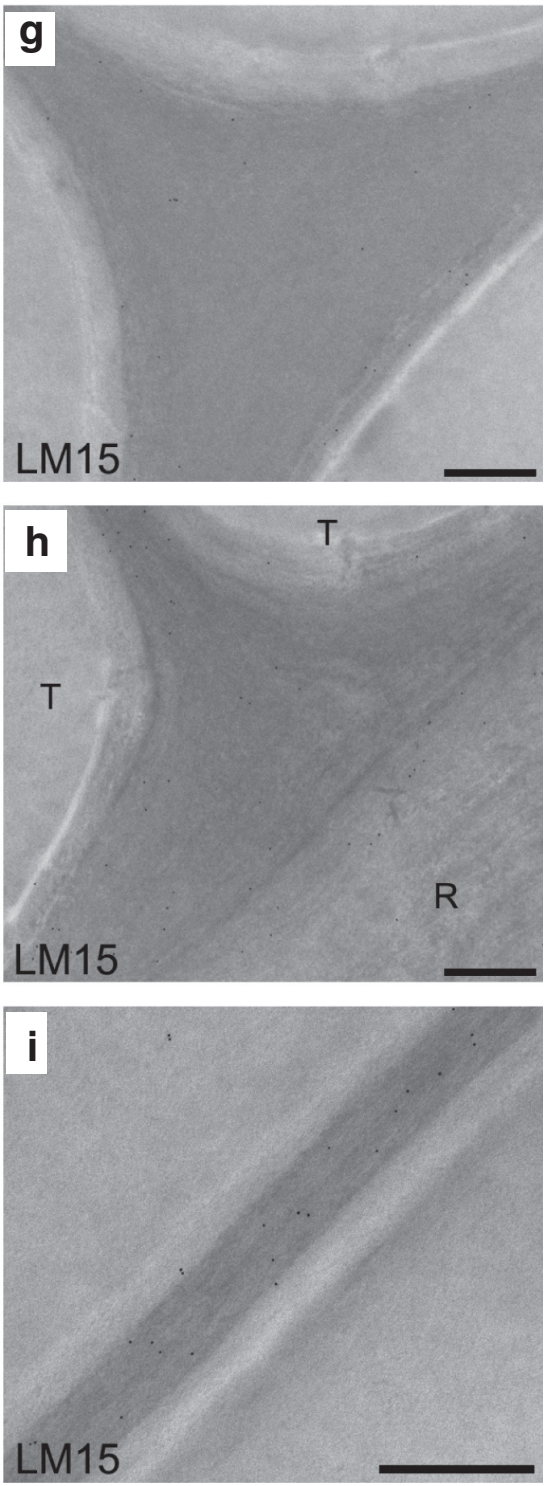

Figure 6 Detection of xyloglucan (LM15) in silver fir and Norway spruce $\mathrm{TMW}_{4 \mathrm{~h}, 220 \circ \mathrm{c}}$.

Note significant reduction of epitopes in $C M L_{c c}$ regions of silver fir $(d-f)$ and Norway spruce $(g-i) T M W$ tracheids $(T)$ and ray cells $(R)$ compared with untreated references $(a-c)$. Scale bar $=500 \mathrm{~nm}$.

of pectin in pit membranes is an important step during incipient fungal colonization (Schwarze 2007). Schwarze and Fink (1998) suggested that preferential degradation of ray and axial parenchyma by the white rot fungus Meripilus giganteus Karst. is closely associated with the distribution of pectin in CML regions of hardwoods at early stages of fungal decay. It can be assumed that degradation of xylan and mannan in $\mathrm{CML}_{\mathrm{cc}}$ regions may also affect the physical and biological features of TMWs, although they are less abundant in this region than pectin and xyloglucan.

\section{Conclusions}

Ultrastructural and chemical changes in $\mathrm{CML}_{\mathrm{cc}}$ regions of thermally modified silver fir and Norway spruce wood (TMWs) were examined by histochemical, ultrastructural, and immunocytochemical methods. Histochemical studies of the TMWs indicate a significant increment of acidic groups in $\mathrm{CML}_{\mathrm{cc}}$ regions. Immunocytochemical results show that noncellulosic polysaccharides are significantly degraded in $\mathrm{CML}_{\mathrm{cc}}$ regions in $\mathrm{TMW}_{4 \mathrm{~h}, 220^{\circ} \mathrm{C}}$ obtained by the Termovuoto process. Results of cytochemical 

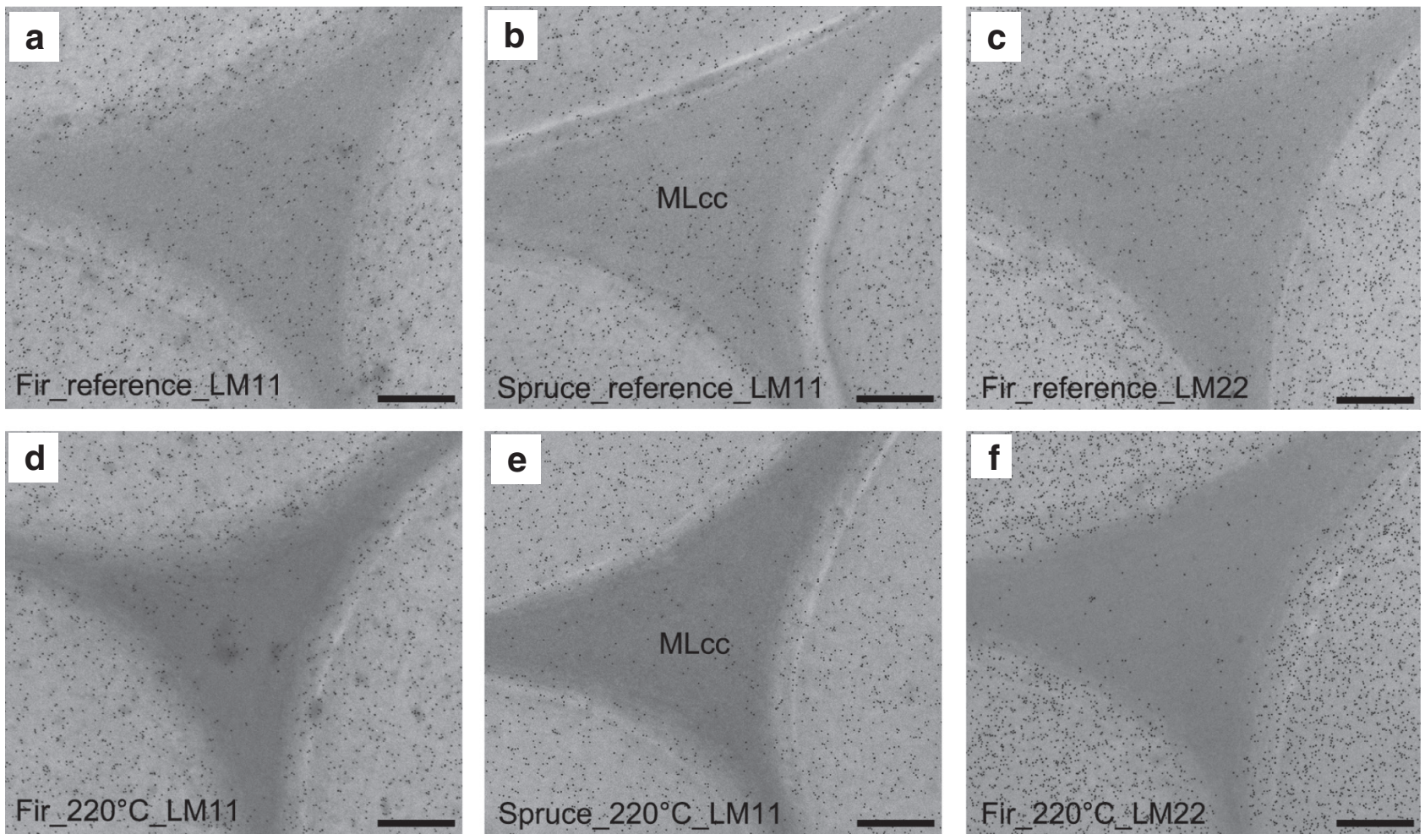

Figure 7 Detection of xylan (LM11) and mannan (LM22) epitopes in silver fir (a, c, d, and f) and Norway spruce (b and e) TMW $\mathrm{Th}_{\mathrm{h}, 220^{\circ} \mathrm{c}}$ tracheids.

Note significant reduction of xylan ( $d$ and e) and mannan (f) epitopes in $\mathrm{CML}_{c c}$ regions of $T M W$ tracheids (d-f) compared with untreated tracheids $(a-c)$. Scale bar $=500 \mathrm{~nm}$.

staining of lignin in $\mathrm{CML}_{\mathrm{cc}}$ regions can be interpreted that the development of electron dense particulates reflects early stages of thermal degradation/alteration. These types of degradation/alteration of noncellulosic polysaccharides and lignin in $\mathrm{CML}_{\mathrm{cc}}$ regions may affect the physical and biological properties of TMWs.

\section{References}

Allegretti, O., Brunetti, M., Cuccui, I., Ferrari, S., Nocetti, M., Terziev, N. (2012) Thermo-vacuum modification of spruce (Picea abies Karst.) and fir (Abies alba Mill.) wood. BioResources 7:3656-3669.

Awoyemi, L., Jones, I.P. (2011) Anatomical explanations for the changes in properties of western red cedar (Thuja plicata) wood during heat treatment. Wood Sci. Technol. 45:261-267.

Biziks, V., Andersons, B., Beḷkova, L., Kapača, E., Militz H. (2013) Changes in the microstructure of birch wood after hydrothermal treatment. Wood Sci. Technol. 47:717-735.

Boonstra, M., Tjeerdsma, B. (2006) Chemical analysis of heat treated softwoods. Holz Roh- Werkst. 64:204-211.

Boonstra, M.J., Rijsdijk, J.F., Sander, C., Kegel, E., Tjeerdsma, B., Militz, H., Van Acker, J., Stevens, M. (2006a) Microstructural
Acknowledgments: The authors gratefully acknowledge funding provided by Formas projects 2009-582 and 2011-416.

Received November 16, 2013; accepted February 3, 2014; previously published online February 26, 2014

and physical aspects of heat treated wood. Part 1. Softwoods. Maderas Cienc. Tecnol. 8:193-208.

Boonstra, M.J., Rijsdijk, J.F., Sander, C., Kegel, E., Tjeerdsma, B., Militz, H., Van Acker, J., Stevens, M. (2006b) Microstructural and physical aspects of heat treated wood. Part 2. Hardwoods. Maderas Cienc. Tecnol. 8:209-217.

Boonstra, M., Van Acker, J., Kegel, E. (2007a) The effect of a two-stage heat treatment process on the mechanical properties of full construction timber. Wood Mater. Sci. Eng. 2:138-146.

Boonstra, M., Van Acker, J., Tjeerdsma, B., Kegel, E. (2007b) Strength properties of thermally modified softwoods and its relation to polymeric structural wood constituents. Ann. For. Sci. 64:679-690. 
Brandt, B., Zollfrank, C., Franke, O., Fromm, J., Göken, M., Durst, K. (2010) Micromechanics and ultrastructure of pyrolysed softwood cell walls. Acta Biomater. 6:4345-4351.

De Vetter, L., Van den Bulcke, J., Van Acker, J. (2010) Impact of organosilicon treatments on the wood-water relationship of solid wood. Holzforschung 64:463-468.

Dieste, A., Krause, A., Mai, C., Sèbe, G., Grelier, S., Militz, H. (2009) Modification of Fagus sylvatica L. with 1,3-dimethylol-4,5-dihydroxy ethylene urea (DMDHEU). Part 2: Pore size distribution determined by differential scanning calorimetry. Holzforschung 63:89-93.

Donaldson, L.A. (1992) Lignin distribution during latewood formation in Pinus radiata D. Don. IAWA Bull. 13:381-387.

Dubey, M.K., Pang, S., Walker, J. (2012) Changes in chemistry, color, dimensional stability and fungal resistance of Pinus radiata D. Don wood with oil heat-treatment. Holzforschung 66:49-57.

Esteves, B.M., Pereira, H.M. (2009) Wood modification by heat treatment: a review. BioResources 4:370-404.

Esteves, B., Velez Marques, A., Domingos, I., Pereira H. (2007) Influence of steam heating on the properties of pine (Pinus. pinaster) and eucalypt (Eucalyptus globulus) wood. Wood Sci. Technol. 41:193-207.

Homan, W.J., Jorissen, A.J.M. (2004) Wood modification developments. Heron 49:360-369.

Jones, L., Seymour, G.B., Knox, J.P. (1997) Localization of pectic galactan in tomato cell walls using a monoclonal antibody specific to ( $1 \rightarrow 4)-\beta$-D-galactan. Plant Physiol. 113:1405-1412.

Kim, J.S., Daniel, G. (2012) Distribution of glucomannans and xylans in poplar xylem and their changes under tension stress. Planta 236:35-50.

Kim, J.S., Awano, T., Yoshinaga, A., Takabe, K. (2011) Distribution of hemicelluloses in warts and the warty layer in normal and compression wood tracheids of Cryptomeria japonica. Mokchae Konghak 39:420-428.

Knox, J.P. (2008) Revealing the structural and functional diversity of plant cell walls. Curr. Opin. Plant Biol. 11:308-313.

Kocaefe, D., Huang, X., Kocaefe, Y., Boluk, Y. (2012) Quantitative characterization of chemical degradation of heat-treated wood. surfaces during artificial weathering using XPS. Surf. Interf. Anal. 45:639-649.

Kollman, F., Fengel, D. (1965) Changes in the chemical composition of wood by heat treatment. Holz Roh-Werkst. 12:461-468.

Li, Y., Wu, Q., Li, J., Liu, Y.,Wang, X.-M., Liu, Z. (2012) Improvement of dimensional stability of wood via combination treatment: swelling with maleic anhydride and grafting with glycidyl. methacrylate and methyl methacrylate. Holzforschung 66:59-66

Mahnert, K.-C., Adamopoulos, S., Koch, G., Militz, H. (2013) Topochemistry of heat-treated and $\mathrm{N}$-methylol melaminemodified wood of koto (Pterygota macrocarpa K. Schum.) and limba (Terminalia superba Engl. et Diels). Holzforschung 67:137-146.

Marcus, S.E., Verhertbruggen, Y., Hervè, C., Ordaz-Ortiz, J., Farkas, V., Pedersen, H.L., Willats, W.G.T., Knox, J.P. (2008) Pectic homogalactronan masks abundant sets of xyloglucan epitopes in plant cell walls. BMC Plant Biol. 8:60.

Marcus, S., Blake, A.W., Benians, T.A.S., Lee, K.J.D., Poyser, C., Donaldson, L., Leroux, O., Rogowski, A., Petersen, H.L.,
Boraston, A., Gilbert, H.J., Willats, W.G.T., Knox, J.P. (2010) Restricted access of proteins to mannan polysaccharides in intact plant cell walls. Plant J. 64:191-203.

Mburu, F., Dumarçay, S., Bocquet, J.F., Petrissans, M., Gérardin, P. (2008) Effect of chemical modifications caused by heat. treatment on mechanical properties of Grevillea robusta wood. Polym. Degrad. Stabil. 93:401-405.

McCartney, L., Marcus, S.E., Knox, J.P. (2005) Monoclonal antibodies to plant cell wall xylans and arabinoxylans. J. Histochem. Cytochem. 53:543-546.

Pfriem, A., Zauer, M., Wagenführ, A. (2010) Alteration of the unsteady sorption behaviour of maple (Acer pseudoplatanus L.) and spruce [Picea abies (L.) Karst.] due to thermal modification. Holzforschung 64:235-241.

Rowell, R.M., Ibach, R.E., McSweeny, J., Nilsson, T. (2009) Understanding decay resistance, dimensional stability and strength changes in heat treated and acetylated wood. 2009 European Conference on Wood Modification, April 27-29, 2009, Stockholm, Sweden. pp. 489-502.

Sandberg, D., Haller, P., Navi, P. (2013) Thermo-hydro and thermohydro-mechanical wood processing: an opportunity for future environmentally friendly wood products. Wood Mater. Sci. Eng. 8:64-88.

Schwarze, F.W.M.R. (2007) Wood decay under the microscope. Fungal Biol. Rev. 21:133-170.

Schwarze, F.W.M.R., Fink, S. (1998) Host and cell type affect the mode of degradation by Meripilus giganteus. N. Phytol. 139:721-731.

Shafizadeh, F. (1984) The chemistry of pyrolysis and combustion. In: The Chemistry of Solid Wood. Ed. Rowell, F. American Chemical Society, Washington, DC. pp. 489-529.

Shi, J., Kocaefe, D., Zhang, J. (2007) Mechanical behavior of Québec wood species heat-treated using ThermoWood process. Holz Roh-Werkst. 65:255-259.

Sivonen, H., Maunu, S.L., Sundholm, F., Jämsä S., Viitaniemi, P. (2002) Magnetic resonance studies of thermally modified wood. Holzforschung 56:648-654.

Sridharan, G., Shankar, A.A. (2012) Toluidine blue: a review of its chemistry and clinical utility. J. Oral Maxillofac. Pathol. $16: 251-255$

Thygesen, L.G., Tang E.E., Hoffmeyer, P. (2010) Water sorption in wood and modified wood at high values of relative humidity. Part I: results for untreated, acetylated, and furfurylated Norway spruce. Holzforschung 64:315-323.

Tjeerdsma, B.F., Militz, H. (2005) Chemical changes in hydrothermal treated wood: FTIR analysis of combined hydrothermal and dry heat-treated wood. Holz Roh-Werkst. 63:102-111.

Verhertbruggen, Y., Marcus, S.E., Haeger, A., Ordaz-Ortiz, J.J., Knox, J.P. (2009) An extended set of monoclonal antibodies to pectic homogalacturonan. Carbohydr. Res. 344:1858-1862.

Willats, W.G.T., Marcus, S.E., Knox, J.P. (1998) Generation of monoclonal antibody specific to $(1 \rightarrow 5)-\alpha$-L-arabinan. Carbohydr. Res. 308:194-152.

Windeisen, E., Wegener, G. (2008) Behaviour of lignin during thermal treatments of wood. Ind. Crops Prod. 27:157-162.

Zollfrank, C., Fromm, J. (2009) Ultrastructural development of the softwood cell wall during pyrolysis. Holzforschung 63: 248-253. 